\title{
GENESIS OF PROFESSIONAL TRAINING FUTURE GEOGRAPHY TEACHERS
}

у статті запропоновано власну періодизацію становлення та розвитку системи профресійної підготовки майбутніх учителів геограсрії. Основою чієї періодизації $є$ не тільки зміни в суспільному житті України, а й розвиток географрічної освіти як системи з якісними зрушеннями у змісті, підходах до вивчення явищ, методах навчання на різних етапах розвитку, зумовленими передусім ресрормами освіти.

Проаналізувавши наукові погляди видатних науковців в галузі профессійної підготовки майбутніх вчителів географрії в історичній ретроспективі та доповнивши їх результатами сучасних психолого-педагогічних досліджень, ми пропонуємо власну періодизацію, яка охоплює п'ять етапів.

Перший етап (1917-1941 роки) - становлення професійної підготовки майбутніх вчителів геограсрії як системи. Для чього періоду характерне виникнення системи педагогічної освіти й нова номенклатура педагогічних спеціальностей із посиленням ролі географрічних дисциплін.

Другий етап (1944-1959 роки) - відновлення роботи системи підготовки майбутніх вчителів геограсрії в післявоєнні роки та ї реформування. В чей час зросла кількість годин на виконання практичних та семінарських занять, збільшився об'єм розробки нових навчальних планів і програм.

Третій етап (1960-1990 роки) - етап розвитку системи університетської географрічної освіти характеризується появою нових географрічних напрямів (ландшафртний аналіз, природокористування, охорона природного середовища), активно розвиваються соціально-економічні дослідження. Великого значення набуває розвиток шкільної геограсрічної освіти, в методику підготовки майбутніх вчителів географрії запроваджено проблемний підхід, покращується матеріальна база та оновлюються технічні засоби навчання. Четвертий етап (1991-2005 роки) - етап фоункціонування системи профресійної підготовки майбутніх вчителів геограсрії в умовах незалежності України, який характеризується рефоормуванням змісту й цілей географочної освіти. Упродовж цього періоду переглядаються методичні засади підготовки майбутніх вчителів, шкільна географрічна освіта спрямовується на просеесійну та творчу самореалізацію майбутнього громадянина. Зроблено перші спроби стандартизації вищої освіти та географрічної зокрема. П'ятий етап (2005 рік - по даний час) - етап приєднання України до Болонського процесу та запровадження кредитно-модульної системи навчання. Відзначається приєднанням України до Болонського прочесу та запровадженням кредитно-модульної системи навчання у вищу школу, що сприяє ефрективній співпраці викладача та студента, збільшення часу їх спілкування в процесі навчання. Даний етап характеризується поглибленням фрундаментальних і прикладних наукових досліджень у вищих навчальних закладах, оновленням освітньо-наукової інсрраструктури, застосуванням наукових результатів у навчальний процес підготовки майбутніх вчителів географрії в Україні.

Ключові слова: періодизація, етапи становлення, наукові погляди, видатні науковці, майбутні вчителі географрії, кредитномодульна система.
The article offers its own periodization of formation and development of the system of professional training of future teachers of geography. The basis of this periodization is not only changes in the social life of Ukraine,but also the development of geographical education as a system with qualitative shifts in content, approaches to the study of phenomena, teaching methods at different stages of development, caused, aboveall, by educational reforms.

Analyzing the scientific views of eminents cholars in the field of vocational training of future geography teachers in historical retrospect and supplementing them with the results of modern psychological and pedagogical research, we propose our own periodization, which covers fivestages. The firststage (1917-1941) - the formation of professional training of future teachers of geography as a system. This periodis characterized by the emergence of a system of pedagogical education and a new nomenclature of pedagogical specialties with the strengthening of the role of geographical disciplines.

The secondstage (1944-1959) - there storation of the system of training future teachers of geography in the post war years and its reform. During this time, the number of hours for practical training and seminars increased, and the volume of development of new curricula and programs increased.

The third stage (1960-1990) - the stage of development of the university geographic education systemis characterized by the emergence of new geographical directions (landscape analysis, nature management, environmental protection), socio-economic research is actively developing. The development of school geography education is of great importance, a problematic approach is introduced in the methodology of training future geography teachers, the material base is improved, and the technical teaching aids are being updated.

The fourth stage (1991-2005) - the stage of functioning of the system of professional training of future teachers of geography in the conditions of independence of Ukraine is characterized by reforming the content and goals of geographic education. During this period, the methodological foundations for the training of future teachers are revised, school geographic education is directed to the professional and creative self-realization of the future citizen. The first attempts were made to standardize higher education and geography in particular.

The fifthstage (2005 - present) - the stage of Ukraine's accession to the Bologna process and the introduction of a credit-module system of education is marked by the accession of Ukraine to the Bologna process and the introduction of a credit-module system of higher education, which facilitates effective cooperation between the teacher and the student, increasing their communication time in the learning process. This stageis characterized by deepening o fbasic and applied scientific researches in higher educational establishments, updating of educational and scientific infrastructure, application of scientific results in educational process of preparation of future geography teachers inUkraine.

Key words: periodization, stages of formation, scientific views, eminent scientists, future teachers of geography, credit-modular system. 
Постановка проблеми у загальному вигляді. Формування системи професійної підготовки вчителів у кожній країні має історичний характер розвитку. Напрями, зміст, фрорми, засоби такої підготовки зумовлені соціально-економічними, історико-культурними чинниками, загальнонаціональними і світовими традиціями. Саме тому розвиток професійної підготовки майбутніх вчителів географрії вплетений у контекст розвитку загальноєвропейської і світової загальноосвітньої педагогічної освіти та внутрішньодержавних соціальноекономічних процесів.

Аналіз останніх досліджень і публікацій. Періодизація становлення та розвитку системи профресійної підготовки майбутніх вчителів географії стала предметом досліджень багатьох українських науковців, серед яких О. Браславська [1], О. Клименко [2], Л. Мельничук [3], О. Надтока [4], Я. Олійник [5], О. Тімець [6], І. Шоробура [7] та ін.

Проте в сучасних умовах виділення етапів становлення та розвитку системи професійної підготовки майбутніх вчителів географрії не отримало належної уваги, що і зумовлює актуальність нашого дослідження.

Мета статті - розробити власну періодизацію та охарактеризувати етапи становлення та розвитку професійної підготовки майбутніх вчителів географріï.

Виклад основного матеріалу дослідження. Проаналізувавши наукові погляди видатних науковців в галузі професійної підготовки майбутніх вчителів геограсрії в історичній ретроспективі та доповнивши їх результатами сучасних психологопедагогічних досліджень, нами запропоновано власну періодизацію, яка охоплює п'ять етапів:

- перший етап (1917-1941 роки) - становлення профресійної підготовки майбутніх вчителів географої як системи;

- другий етап (1944-1959 роки) - відновлення роботи системи підготовки майбутніх вчителів географрії в післявоєнні роки та її рефрормування;

- третій етап (1960-1990 роки) - розвиток системи університетської географрічної освіти та виокремлення прикладної геограсрії;

- четвертий етап (1991-2005 роки) - фрункціонування системи профресійної підготовки майбутніх вчителів географрії в умовах незалежності України;

- п'ятий етап (2005 рік - по даний час) - приєднання України до Болонського процесу та запровадження кредитно-модульної системи навчання.

Детальніше охарактеризуємо визначені нами етапи.

\section{Перший етап.}

На першому етапі (1917-1941 роки) відбувається становлення професійної підготовки майбутніх вчителів географії як системи.

До початку XX століття фрізико-географрічні поняття вже стали звичним явищем у шкільних географрічних курсах. Вони почали складатися у певну систему ще у 30-х роках минулого століття (О. Надтока). Зокрема, у 1917 році почався набір студентів на географрічну спеціальність у Херсонському педагогічному інституті. У 1926 році в Харкові засновано Інститут географії і картографії. У 1930-1940 роках в Україні виникло чимало наукових закладів, де велися географрічні та близькі до геограорічних дослідження [4].

На думку О. Тімець, для цього періоду характерні нез'ясованість місця географрії в системі наук до 30-х років XX ст. та утвердження її як самостійного загальноосвітнього предмета після низки урядових постанов, починаючи з 1931 року. В цей час розпочинається фрормування засад вітчизняної методики навчання географії, видають спеціальні методичні посібники, рекомендації для вчителів, що сприяло розвиткові географрічної науки, утвердженню її здобутків у вищій школі [6, с. 29].

Таким чином, на етапі становлення професійної підготовки майбутніх вчителів географії значна увага приділяється вивченню географрічних дисциплін, фрормуються засади вітчизняної методики навчання географії, видаються методичні посібники та підручники географрічного спрямування. Для цього періоду характерне виникнення системи педагогічної освіти й нова номенклатура педагогічних спеціальностей із посиленням ролі геограсрічних дисциплін. Виникла значна кількість наукових закладів географічного спрямування, де відбувалась підготовка майбутніх вчителів географії.

Другий етап.

Другий етап припадає на 1944-1959-ті рр. й вирізняється відновленням роботи системи підготовки майбутніх вчителів географрії в післявоєнні роки та її ресормуванням.

У 50-х роках XX ст. ухвалено державну постанову про введення загальної обов'язкової десятирічної освіти на основі політехнічного навчання, де географії відведено одне з центральних місць, що сприяло підвищенню вимог до підготовки майбутніх учителів географрії та проходження ними практики в школі (Л. Мельничук) [3] В цей час започатковуються навчальні курси 3 вивчення географії республіки, області, району, що передбачають використання краєзнавчого матеріалу (О. Надтока) [4, с. 232].

У працях цього періоду з економічної географії створено методологічні основи структурного аналізу виробничо-територіальних комплексів; роботи 3 комплексного районного планування території з багатопрофрільним народним господарством; фрізико-географи розглядали питання районування України, де вперше дано характеристику всіх регіональних одиниць за єдиним принципом (Я. Олійник) [5, с. 42-43].

Таким чином, другий етап (1944-1959 роки) етап відновлення роботи системи підготовки май- 
бутніх вчителів географрії в післявоєнні роки та ї реформування - характеризується збільшенням термінів навчання для підготовки вчителів. Зросла кількість годин на виконання практичних та семінарських занять, збільшився об'єм розробки нових навчальних планів і програм. Зміст вищої географрічної освіти залежить від досягнень географрічної науки, що поетапно вдосконалюється та видозмінюється.

Третій етап.

Наступною сходинкою став третій етап (19601990-ті роки), який характеризувався розвитком системи університетської географрічної освіти та виокремленням прикладної географрії.

60-ті роки - розвиток радянської системи географрічної освіти та наростання суперечностей і явищ стагнації у системі підготовки майбутніх вчителів географії. Хрущовська «відлига» стала значним поштовхом для відродження творчого потенціалу педагогічних сил, що стимулювало розвиток науки та системи освіти.

70-і роки - етап розвитку шкільної географрічної освіти. В ці роки знову повертаються до лінійної структури викладання географії, з'являються нові навчальні плани, програми, підручники.

У 70 - 80-х роках у методику навчання геограсрії поступово входить проблемний підхід, розширився арсенал застосування методів навчання. Все це відбувалося на тлі покращення матеріальної бази навчання географії - карти, таблиці, довідники, енциклопедії та технічні засоби навчання: проектори, фрільмоскопи, кінофільми, діафрільми тощо (Я. Олійник) [5].

80-і - 1990 рр. - період наростання суперечностей між системою географрічної освіти та процесами демократизації зумовили зміни якісні зрушення в геограсрічній освіті лише з другої половини 80-х рр. Особливістю 90-х рр. є зростання політичної самосвідомості українського народу, його прагнення до незалежності. Спостерігається і відповідна переорієнтація навчання майбутніх вчителів географії (І. Шоробура) [7, с. 760].

у досліджуваний період розвивалися теоретичні питання, які стосувались економічної географрії - це фрормування і функціонування виробничо-територіальних комплексів, фрормування складників виробничо-територіальних комплексів, застосування картографрічного методу під час вивчення економіко-географрічних об'єктів, проблеми фрормування систем розселення, міграції населення і трудових ресурсів, ландшафттні дослідження. Картографічні дослідження розвивались у двох напрямах: теоретичні і методичні напрацювання та створення карт; використання математичних методів в економічній і фрізичній географії. $[5$, c. 46].

Отже, третій етап (1960-1990 роки) - етап розвитку системи університетської географрічної освіти - характеризується появою нових географрічних напрямів (ландшафтний аналіз, природокористування, охорона природного середовища), активно розвиваються соціально-економічні дослідження. Великого значення набуває розвиток шкільної географічної освіти, в методику підготовки майбутніх вчителів географрії запроваджено проблемний підхід, покращується матеріальна база та оновлюються технічні засоби навчання. Таким чином, на третьому етапі було започатковано розвиток педагогічної психології та продовжено дослідження щодо формування особистості фрахівця в умовах навчальної діяльності.

Четвертий етап.

Наступною сходинкою став четвертий етап 1991-2005-ті роки, який розпочався в умовах незалежності України.

Із початком 90-х років XX ст. пов'язують новітній етап розвитку географрічної освіти у вищих педагогічних навчальних закладах та школах України.

Із здобуттям Україною незалежності змінюються суспільно-культурні потреби, переглядаються окремі методичні засади підготовки майбутніх вчителів відповідно до парадигми особистісно орієнтованого навчання та 3 орієнтацією на національне виховання. Зважаючи на невпинний розвиток науково-технічного прогресу, процеси глобалізації, високу інфрормаційну насиченість суспільства, шкільна геограсрічна освіта спрямовується на професійну та творчу самореалізацію майбутнього громадянина (О. Надтока) [4, с. 230.]

Як зазначає О. Браславська, процеси глобалізації, комп'ютеризації сприяли підвищенню потреб особистості в розширенні знань із географрії та вмінь їх застосовувати в життєдіяльності. 3'являються перші спроби стандартизації освіти взагалі та геограсрічної зокрема [1, с. 56.].

Виокремлено нові вимоги до рівня фрахової підготовки вчителів географії, сфрормована стійка система вищої географічної освіти, оновлення ії змісту й структури. Нагальною потребою в професійній підготовці майбутнього вчителя географрії стало вивчення й узагальнення передового педагогічного досвіду, кращих світових здобутків, упровадження різноманітних науково-організаційних фрорм діяльності закладів середньої й вищої освіти, заміна авторитарності на демократичні принципи навчання, зміна структури співпраці викладачів та студентів для стимулювання творчості, ініціативності, професіоналізму, відкритості системи географрічної освіти на основі нових прогресивних світових концепцій та компетентнісного підходу (О. Тімець) [6].

Таким чином, четвертий етап (1991-2005 роки) етап ффункціонування системи професійної підготовки майбутніх вчителів географрії в умовах незалежності України - характеризується реформуванням змісту й цілей географрічної освіти. 
Упродовж цього періоду значна увага приділялася науково-методичним основам економіко-географрічних досліджень; проблемам історії національної географії; оцінці природно-ресурсного потенціалу; проблемам раціонального природокористування та екологізації географії. Переглядаються методичні засади підготовки майбутніх вчителів, шкільна географрічна освіта спрямовується на професійну та творчу самореалізацію майбутнього громадянина. Зроблено перші спроби стандартизації вищої освіти та географрічної зокрема. Зміщено акценти 3 репродуктивного відтворення географрічної інфрормації на розвиток пізнавальної активності й географрічного мислення студентів; уніфрікацію змісту фахової підготовки студентів-географрів; урахування проблемного підходу до навчання географії; запровадження в навчальний процес ВНЗ активних методів навчання; підсилення мотивації навчання 3 урахуванням національних і регіональних чинників у змісті географрічної освіти.

П'ятий етап.

П'ятий етап розпочався 32005 року і триває до теперішнього часу. У цей період відбулося приєднання України до Болонського процесу та запровадження кредитно-модульної системи навчання у вищу школу.

Він орієнтований на активне входження освіти і науки у вищих навчальних закладах України до європейської та світової спільноти. Швидка зміна умов життя змушує шукати нові підходи до підготовки фрахівців, які будуть здатні працювати у XXI столітті.

Сучасним стратегічним пріоритетом визнається впровадження національної інноваційної моделі розвитку України, що, зокрема, передбачає удосконалення освітньо-наукової інфрраструктури, системи проведення фундаментальних і прикладних наукових досліджень у вищих навчальних закладах, упровадження наукових результатів у навчальний процес (О. Клименко, Г. Михайлюк) [2].

Перехід до кредитно-модульної системи навчання дає можливість українським ВНЗ проводити підготовку фрахівців, здатних до постійного оновлення наукових знань в умовах ринкової економіки, професійної мобільності та швидкої адаптації до змін у соціально-культурному середовищі, продовжити освіту або здобути відповідну кваліфрікацію за кордоном на базі певного закінченого циклу освіти.

Саме для цього й існує система тьюторів, робота яких полягає у наданні консультацій студентам 3 приводу того, коли і які предмети їм краще обирати та певні правила переходу від одного модуля до іншого. Треба зазначити, що Британська тьюторська система дещо корелює із елементами українського освітнього процесу, зокрема, із призначенням кураторів для груп сту- дентів чи наукових керівників для дипломантів та аспірантів [5].

Варто глибше розглянути питання інтеграції 3 різними географічними та іншими гуманітарними дисциплінами в межах єдиних інтегрованих програм; вибірковості в ознайомленні з різними регіонами світу за проблемного навчання; моделюванні навчального процесу, інноваційності у навчанні [1].

Таким чином, п'ятий етап (2005 рік - по даний час) відзначається приєднанням України до Болонського процесу та запровадженням кредитно-модульної системи навчання у вищу школу, що сприяє ефективній співпраці викладача та студента, збільшенню часу їх спілкування в процесі навчання. Активне входження освіти і науки до європейської та світової спільноти дає можливість готувати майбутніх педагогів, здатних до постійного оновлення наукових знань в умовах нових викликів XXI століття. Це сприяє профресійній мобільності та можливостям продовжити освіту або здобути відповідну кваліфрікацію за кордоном на базі певного закінченого циклу освіти в Україні. Даний етап характеризується поглибленням фундаментальних і прикладних наукових досліджень у вищих навчальних закладах, оновленням освітньо-наукової інфрраструктури, застосуванням наукових результатів у навчальний процес підготовки майбутніх вчителів геограсрії в Україні.

Висновки. В ході дослідження нами запропоновано власну періодизацію основних етапів становлення та розвитку системи профресійної підготовки майбутніх учителів географії в історичній ретроспективі. Основою цієї періодизації $€$ не тільки зміни в суспільному житті України, а й розвиток географрічної освіти як системи 3 якісними зрушеннями у змісті, підходах до вивчення явищ, методах навчання на різних етапах розвитку, зумовленими передусім рефрормами освіти. Вивчення таких зрушень і реформ географрічної освіти викликає інтерес не тільки з точки зору змін у методичній науці, технологіях навчання, але i тим, у яких історичних і культурних умовах вони відбувалися, наступністю в освітньому процесі і на окремих його етапах.

Перспективи подальших досліджень полягають в аналізі проблем профресійної підготовки майбутніх вчителів географії у педагогічній теорії.

\section{БІБЛІОГРАФІЧНИЙ СПИСОК:}

1. Браславська О. Вітчизняна географрічна освіта: історичні аспекти XVII - поч. XX століття. Проблеми підготовки сучасного вчителя. 2014. № 9(1). С. 201-208.

2. Клименко О. Болонський процес в Україні: в пошуку національної моделі системи вищої освіти. Наукові записки. Том 71 Педагогічні, психологічні науки та соціальна робота. 2007. С. 37-43.

3. Мельничук Л.І. Становлення і розвиток шкільної географічної освіти в Україні в першій половині 
XX століття : автореф. дис. ... канд. пед. наук. Київ, 2004. 19 c.

4. Надтока О.Ф. Аспекти розвитку методики навчання географії на основі еволюціонування фрізико-географрічних понять. Педагогічна освіта: теорія і практика. 2014. Вип. 17. С. 229-236.

5. Олійник Я. Географрічна наука в Україні: становлення і розвиток. Київ : Ніка-Центр. 2007. 148 с.
6. Тімець О.В. Історичні віхи просресійної підготовки майбутніх учителів геограсрії. Географрія та основи економіки в школі. 2011. № 11-12 (грудень). С. 26-35.

7. Шоробура І.М. Особливості періодизації становлення та розвитку шкільної географрічної освіти (XIX-XX століття). Педагогічний дискурс. 2013. Вип. 15. С. 758-763. 